\title{
INFORMATION TECHNOLOGY, SERVICE QUALITY AND CUSTOMER SATISFACTION
}

\author{
Hal Records, Bryant University, hrecords@bryant.edu \\ Suhong Li, Bryant University, sli@bryant.edu \\ Robert Behling, Arrowrock Industries, behlingr@hotmail.com
}

\begin{abstract}
Information technology mediated customer service is a reality of the $21^{\text {st }}$ century. Getting to speak to a human while seeking customer service is getting harder and harder to do. This paper looks at various types of retail purchasing and attempts to assess the relative effectiveness of three types of customer service delivery. These are in store and in person, through a computer or mobile device, and by telephone. Results suggest that companies should review their strategies for customer service and adjust their rate of IT mediated customer service to more closely match customer willingness to embrace these changes.
\end{abstract}

Keywords: Customer service technology, customer service metrics, retail self-service checkout, chatter bots, electronic shopping, electronic payment, point of sale systems.

\section{INTRODUCTION}

Organizations continue to face competitive challenges both from home and overseas, and meeting these challenges often impacts customer brand loyalty and product profitability. Spending more for improved customer service may lead to lower profitability. When product differentiation cannot be achieved, there are two general strategies that can be employed to remain competitive: price differentiation and service differentiation. The focus of this study is limited to investigating service differentiation. Service can be defined as customer care and customer support. Most organizations have some form of customer service, as there will always be times when a customer has a need, a problem, or needs information.

With the growing deployment of self-service technologies, businesses need to determine their most favorable mix of traditional human service with IT mediated service. (Israeli \& Brown, 2015) Many companies are cultivating Customer Service by structuring the business model to meet and satisfy customer requirements. (Domegan \& Donaldson 1992) For example: McDonalds has extended the breakfast menu to be served the entire day rather than just in the morning. Kentucky Fried Chicken has "bundled" menu offerings, and no longer sells certain items individually. McDonald's customer service strategy may lead to a positive outcome, more sales; KFC may lead to a negative outcome, the customer does not want the bundle of items, only a single item. In any case, the ultimate objective of customer service is to assist customers in solving a problem or meeting a need.

Many see information technology as the modern driving force for customer service innovation. More than twenty five years ago, (Clarke \& Murray 1990) argued that the greatest unrealized potential of IT is in the area of customer service. Recent research by (Pulach \& Wunderlich 2016) studying B2B customers, however, found that despite their potential, gaining acceptance of technology based services presents significant management challenges. Davis (1989) The study also found that customers perceived technology based services as high risk. A recent study of the value of self- service (Scherer,Wunderlich, \& von Wangenheim, 2015) reported that while self-service may increase productivity and reduce the cost of service delivery, technology-based self-service may not always lead to desired results and may harm customer retention. Efforts in the area of chatter bots (Chakrabati \& Luger, 2015) underscore the difficulties in both typed and oral customer interface with automated systems. In spite of these obstacles, deployment of digital technologies is resulting in utilizing Information technology to replace humans in meeting service demands. 


\section{Issues in Information Systems \\ Volume 18, Issue 1, pp. 1-10, 2017}

Moore's Law states that the number of transistors in a dense integrated circuit will double every two years, Moore (1965) therefore overall processing capabilities will double, while the cost stays about the same. Substituting technology for humans to provide customer service makes economic sense for organizations, because the price of technology continues to drop per unit of processing, while the price of human labor stays the same or continues to rise. This has led to such things as human-less automated telephone attendant systems to respond to telephone inquiries, internet driven service request systems, self-checkout stations at grocery retailers (such as Stop and Shop and Publix) (Lee \& Lyu, 2016), (McWilliams \& Anistal, 2016) and home improvement retailers (such as Home Depot and Lowes), self-ordering and paying devices at food retailers such as Chili's, and of course automated teller machines (ATMs) at banks and kiosks.

A study by Accenture (Quering, DeAngelis \& Gasull, 2016) found that $83 \%$ of U.S. consumers prefer dealing with human beings rather than digital channels, and that human interaction is vital to customer satisfaction. Humans generally prefer not interacting with technology or machines when they require service. Human interaction, therefore, continues to be a vital element in successfully meeting customer service expectations. When economics come into play and service is outsourced off shore, even when humans are utilized, language may become a problem. Example: Many foreign countries may provide lower cost service representatives, but can these representatives communicate effectively, solve problems, and meet U.S. customer expectations? The Accenture study (Quering, DeAngelis \& Gasull, 2016) found that cultural differences and language issues influence customer ratings.

Virtually all organizations claim to strive for superior customer service, but they also must live with finite budgets. In almost all situations great customer service is expected, but when delivered may not build customer loyalty. It is expected, and those expectations are met. Poor customer service is generally unacceptable, and may drive customers to seek alternative providers, and will often negatively affect customer loyalty.

How does an organization verify that they are providing excellent customer service? One way is to measure customer satisfaction. Measurement of customer satisfaction often includes asking the customer to complete a brief survey, either at the time of service or after the fact. The survey provides a window to view those utilizing the service. Customer service quality begins with the business decisions establishing customer service response systems; customer satisfaction is how customers react to these systems when they have a problem that needs to be addressed. Whatever the process, measuring customer service effectiveness is vitally important Clark \& Murray, 1990). Measuring service quality generally involves measuring both objective and subjective outcomes: were your needs met, and were they met in a manner that was acceptable to you.

This paper will focus on customer service satisfaction. Our objective is to determine if today's customers are satisfied with customer service systems that are currently in place.

\section{METHODOLOGY}

In order to evaluate customer service satisfaction with IT mediated service we first identified five types of retail purchasing done by potential survey respondents. These types were selected because nearly everyone frequently makes these purchases. They are one retail, two eating out, three banking, four travel and five entertainment. Next we identified three modes by which purchasing can be done, first in store and in person; second through a computer, mobile device or smart phone (online); and third by voice telephone. We then designed a Qualtrics-based survey to discover how people perceive the relative value of each means of purchasing within each type of purchasing experience. GLM (General Linear Model) Repeated Measures was then used to test whether people's perception of customer service quality differs among three modes of purchasing.

The survey was distributed largely to students at a small private northeastern university with 234 valid respondents. Table 1 shows demographic Information about the survey population, $76 \%$ of the students are sophomores and a majority of them (72\%) reside in suburban areas. Among the respondents, $61 \%$ are male and $39 \%$ are female. 
Table 1. Demographics Information

\begin{tabular}{|l|l|l|}
\hline & & Percent (Number) \\
\hline \multirow{3}{*}{ Gender } & Male & $60.7 \%(142)$ \\
\cline { 2 - 3 } & Female & $39.3 \%(92)$ \\
\hline \multirow{4}{*}{$\begin{array}{l}\text { Academic } \\
\text { Year }\end{array}$} & Freshman & $0.4 \%(1)$ \\
\cline { 2 - 3 } & Sophomore & $76.1 \%(178)$ \\
\cline { 2 - 3 } & Junior & $16.7 \%(39)$ \\
\cline { 2 - 3 } $\begin{array}{l}\text { Home } \\
\text { Location }\end{array}$ & Senior & $6.8 \%(16)$ \\
\cline { 2 - 3 } & Urban & $15.4 \%(36)$ \\
\cline { 2 - 3 } & Suburban & $72.6 \%(170)$ \\
\cline { 2 - 3 } & Rural & $12.0 \%(28)$ \\
\hline
\end{tabular}

Table 2 shows the types of hardware devices owned by respondents and their inclination toward technology adoption as described in technology adoption modeling (TAM). Davis (1989) It is interesting to note the high availability of owned hardware devices. Nearly $100 \%$ have laptops and web-enabled smart phones, and nearly $50 \%$ have tablet computers, hence many have three personal electronic devices.

Table 2. Devices

\begin{tabular}{|l|l|}
\hline Devices I Own & Percent (Number) \\
\hline Laptop/Computer & $100 \%(234)$ \\
\hline E-Reader (Kinder Fire, Nook, etc.) & $15.4 \%(36)$ \\
\hline Tablet (iPad, Samsung Note, etc.) & $47.9 \%(112)$ \\
\hline Smart Phone & $98.3 \%(230)$ \\
\hline Apple Watch & $6.8 \%(16)$ \\
\hline $\begin{array}{l}\text { I am always among the first to adopt } \\
\text { new technology and gadgets }\end{array}$ & $7.3 \%(17)$ \\
\hline Strongly Agree (Eagle Beaver) & $29.1 \%(68)$ \\
\hline Agree (Early Adopter) & $39.7 \%(93)$ \\
\hline $\begin{array}{l}\text { Neither Agree nor Disagree (Early } \\
\text { Majority) }\end{array}$ & $20.9 \%(49)$ \\
\hline $\begin{array}{l}\text { Disagree (Late Majority) } \\
\text { Strongly Disagree (Technically } \\
\text { Adverse) }\end{array}$ & $3.0 \%(7)$ \\
\hline
\end{tabular}

Given the age, hardware availability and pro-technology bias associated with this population it was anticipated that survey results would be more friendly toward the use of IT mediated service than that of the purchasing population as a whole.

\section{DATA ANALYSIS}

Table 3 shows that a majority of students prefer in store and in person for retail purchasing and eating out. For ordering tickets for travel and entertainment, they prefer computer/mobile device. For banking, about half of the students (48\%) prefer in person services, and about one third (35\%) prefer computer and mobile devices, and the rest (14\%) prefer phone. 


\section{Issues in Information Systems \\ Volume 18, Issue 1, pp. 1-10, 2017}

For each of the five purchasing categories (Retail, Eating Out, Banking, Travel, and Entertainment), 7 items for measuring customer services quality (see table 4 ) were developed and students were asked to rate each service quality (on a scale of 1-5) based on where purchasing was conducted (in store and in person, computer/mobile, or phone). GLM (General Linear Model) Repeated Measures was then used to test whether there is a significant perception difference of customer service quality among three modes of purchasing (in-store and in person, computer/mobile device, and phone).

Table 3. Student Preferences by Type of Purchasing

\begin{tabular}{|c|l|l|l|}
\hline \multirow{2}{*}{ Type of Purchasing } & \multicolumn{3}{|c|}{ Respondent Preferences } \\
\cline { 2 - 4 } & In Store and in Person & $\begin{array}{l}\text { Through } \\
\text { Computer/Mobile Device }\end{array}$ & Phone \\
\hline Retail & $66.7 \%(156)$ & $31.6 \%(74)$ & $1.3 \%(3)$ \\
\hline Eating Out & $84.6 \%(198)$ & $8.5 \%(20)$ & $5.1 \%(12)$ \\
\hline Banking & $47.9 \%(112)$ & $34.6 \%(81)$ & $13.7 \%(32)$ \\
\hline Travel & $16.7 \%(39)$ & $77.4 \%(181)$ & $3.4 \%(8)$ \\
\hline Entertainment & $30.3 \%(71)$ & $62.0 \%(145)$ & $5.6 \%(13)$ \\
\hline
\end{tabular}

For each service quality measure, Mauchly's test of sphericity was conducted to see whether variances of the differences between all possible pairs of modes of purchasing (in-store, computer/mobile device and phone) are equal. The results show that Mauchly's test of sphericity are not met for all questions. Therefore, Greenhouse-Geisser Correction measure will be used to test mean difference between three modes of purchasing. The results show that there exists significant difference between the three modes of purchasing for each category of purchasing (See Tables 4-8 and Figures 1-5).

Table 4. Retail Purchasing

\begin{tabular}{|l|c|c|c|c|c|c|}
\hline & \multicolumn{3}{|c|}{ Mean for Each Mode of Purchasing } & \multicolumn{3}{|c|}{ Greenhouse-Geisser } \\
\hline & $\begin{array}{l}\text { In Store } \\
\text { and In } \\
\text { Person }\end{array}$ & $\begin{array}{l}\text { Computer } \\
\text { /Mobile } \\
\text { Device }\end{array}$ & Phone & $\begin{array}{l}\text { Degree of } \\
\text { Freedom }\end{array}$ & F & Significance \\
\hline $\begin{array}{l}\text { You felt welcome to the store/ } \\
\text { website/phone }\end{array}$ & 3.97 & 3.78 & 4.11 & 1.53 & 7.76 & $\mathbf{0 . 0 0}$ \\
\hline $\begin{array}{l}\text { You were able to locate what } \\
\text { you wanted }\end{array}$ & 3.85 & 4.20 & 4.27 & 1.67 & 12.70 & $\mathbf{0 . 0 0}$ \\
\hline $\begin{array}{l}\text { Checkout and payment was } \\
\text { quick enough }\end{array}$ & 3.65 & 4.24 & 4.35 & 1.76 & 32.50 & $\mathbf{0 . 0 0}$ \\
\hline $\begin{array}{l}\text { You felt secure in doing your } \\
\text { transactions }\end{array}$ & 4.25 & 3.75 & 3.99 & 1.58 & 15.36 & $\mathbf{0 . 0 0}$ \\
\hline Total waiting time is reasonable & 3.64 & 4.24 & 4.30 & 1.63 & 34.05 & $\mathbf{0 . 0 0}$ \\
\hline $\begin{array}{l}\text { Total time to complete } \\
\text { transaction was reasonable }\end{array}$ & 3.89 & 4.19 & 4.39 & 1.67 & 18.81 & $\mathbf{0 . 0 0}$ \\
\hline $\begin{array}{l}\text { Customer Service met your } \\
\text { expectations }\end{array}$ & 3.88 & 3.68 & 4.20 & 1.66 & 19.91 & $\mathbf{0 . 0 0}$ \\
\hline
\end{tabular}




\section{Issues in Information Systems}

Volume 18, Issue 1, pp. 1-10, 2017

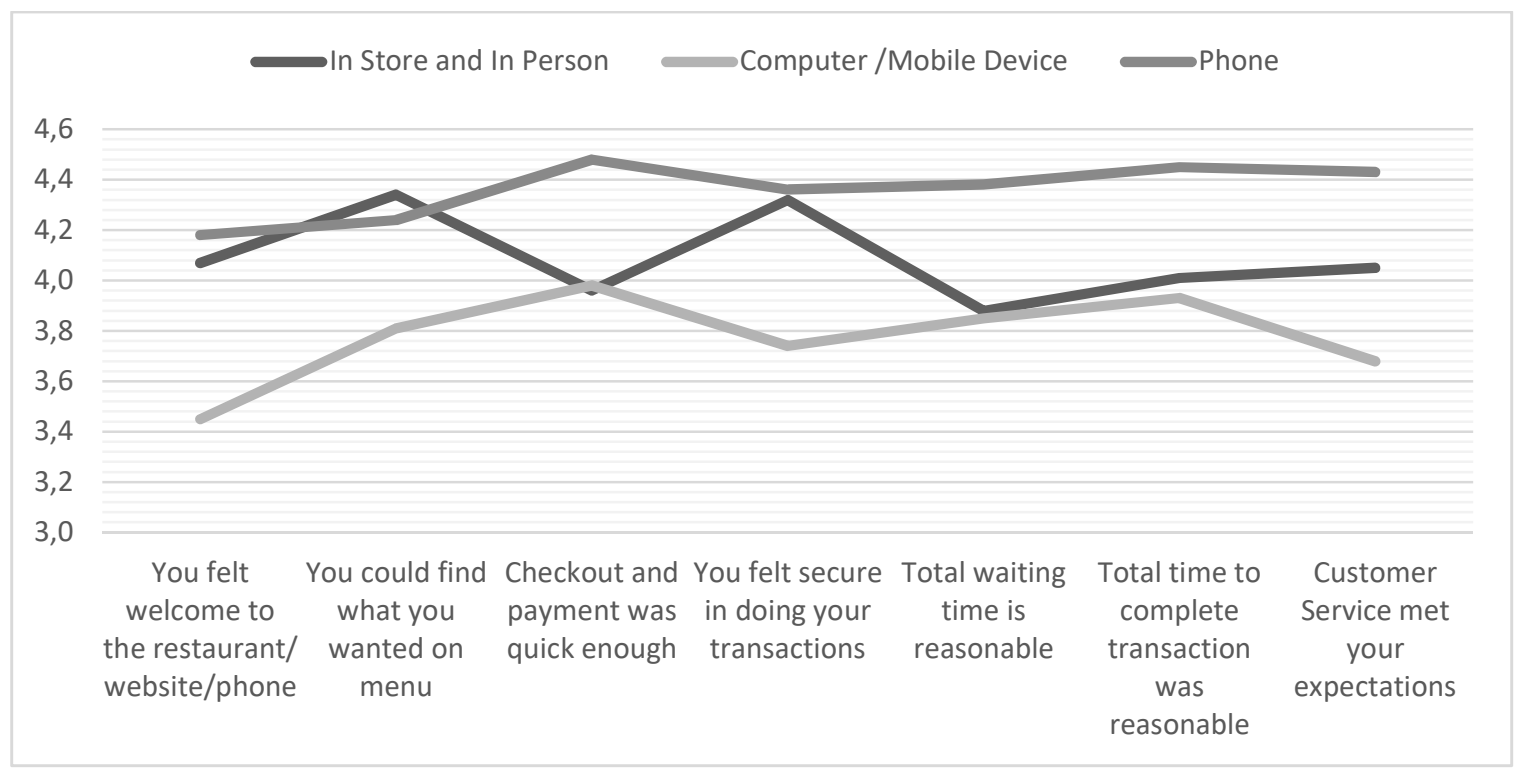

Figure 1. Retail Purchasing

Table 4 shows that for retail purchasing, there exist significant difference among three modes of purchasing for each metric of customer service quality. Surprisingly, the students chose in store and in person as their most preferred method of retail purchasing, however, purchasing by phone received highest mean for all service quality measures except item 3 (you felt secure in doing your transaction) where in store and in person received highest mean.

Table 5. Eating Out

\begin{tabular}{|l|r|r|r|r|r|c|}
\hline & \multicolumn{3}{|c|}{$\begin{array}{l}\text { Mean for Each Mode of Ordering } \\
\text { Eating out }\end{array}$} & \multicolumn{3}{c|}{ Greenhouse-Geisser } \\
\hline & $\begin{array}{l}\text { In Store } \\
\text { and In } \\
\text { Person }\end{array}$ & $\begin{array}{l}\text { Computer } \\
\text { /Mobile } \\
\text { Device }\end{array}$ & Phone & $\begin{array}{l}\text { Degree of } \\
\text { Freedom }\end{array}$ & F & Significance \\
\hline $\begin{array}{l}\text { You felt welcome to the } \\
\text { restaurant/ website/phone }\end{array}$ & 4.07 & 3.45 & 4.18 & 1.75 & 31.93 & $\mathbf{0 . 0 0}$ \\
\hline $\begin{array}{l}\text { You could find what you wanted } \\
\text { on menu }\end{array}$ & 4.34 & 3.81 & 4.24 & 1.70 & 19.05 & $\mathbf{0 . 0 0}$ \\
\hline $\begin{array}{l}\text { Checkout and payment was } \\
\text { quick enough }\end{array}$ & 3.96 & 3.98 & 4.48 & 1.94 & 19.97 & $\mathbf{0 . 0 0}$ \\
\hline $\begin{array}{l}\text { You felt secure in doing your } \\
\text { transactions }\end{array}$ & 4.32 & 3.74 & 4.36 & 1.69 & 29.83 & $\mathbf{0 . 0 0}$ \\
\hline Total waiting time is reasonable & 3.88 & 3.85 & 4.38 & 1.86 & 23.32 & $\mathbf{0 . 0 0}$ \\
\hline $\begin{array}{l}\text { Total time to complete } \\
\text { transaction was reasonable }\end{array}$ & 4.01 & 3.93 & 4.45 & 1.78 & 25.70 & $\mathbf{0 . 0 0}$ \\
\hline $\begin{array}{l}\text { Customer Service met your } \\
\text { expectations }\end{array}$ & 4.05 & 3.68 & 4.43 & 1.82 & 40.77 & $\mathbf{0 . 0 0}$ \\
\hline
\end{tabular}




\section{Issues in Information Systems}

Volume 18, Issue 1, pp. 1-10, 2017

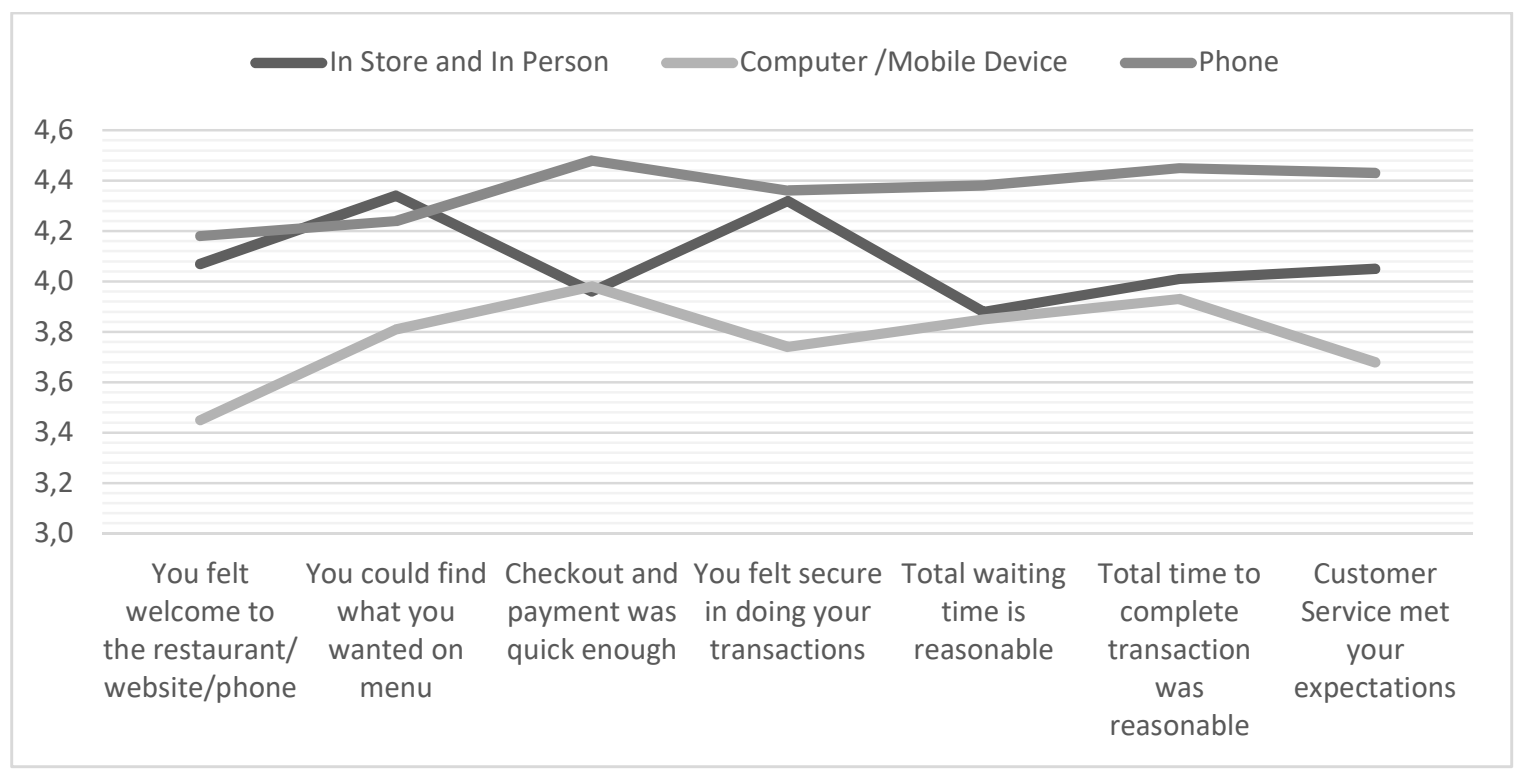

Figure 2. Eating-Out

Table 5 shows that for eating out, there exist significant difference among three modes. Again, results in previous section show that the students chose in store and in person as their most preferred method of ordering eating out, however, ordering by phone received highest mean for all service quality measures except item 2 (you could find what you wanted on menu). Ordering by computer/mobile device has the lowest mean for all measures except two, checkout and payment was quick enough, and total waiting time is reasonable.

Table 6. Banking

\begin{tabular}{|l|r|r|r|r|r|r|}
\hline & \multicolumn{3}{|c|}{ Mean for Each Mode of Banking } & \multicolumn{3}{|c|}{ Greenhouse-Geisser } \\
\hline & $\begin{array}{l}\text { In Store } \\
\text { and In } \\
\text { Person }\end{array}$ & $\begin{array}{l}\text { l-Mobiler } \\
\text { Device }\end{array}$ & \multicolumn{1}{|l|}{ Phone } & $\begin{array}{l}\text { Degree of } \\
\text { Freedom }\end{array}$ & F & Significance \\
\hline $\begin{array}{l}\text { You felt welcome to the bank/ } \\
\text { website/phone }\end{array}$ & 4.29 & 4.06 & 3.82 & 1.93 & 24.60 & $\mathbf{0 . 0 0}$ \\
\hline $\begin{array}{l}\text { You could complete those } \\
\text { transactions you wished to do }\end{array}$ & 4.45 & 4.11 & 3.79 & 1.81 & 41.13 & $\mathbf{0 . 0 0}$ \\
\hline $\begin{array}{l}\text { You felt secure in doing your } \\
\text { transactions }\end{array}$ & 4.51 & 3.89 & 3.60 & 1.71 & 67.80 & $\mathbf{0 . 0 0}$ \\
\hline Total waiting time is reasonable & 3.99 & 4.26 & 3.80 & 1.88 & 18.14 & $\mathbf{0 . 0 0}$ \\
\hline $\begin{array}{l}\text { Total time to complete } \\
\text { transaction was reasonable }\end{array}$ & 4.11 & 4.21 & 3.86 & 1.82 & 11.74 & $\mathbf{0 . 0 0}$ \\
\hline $\begin{array}{l}\text { Customer Service met your } \\
\text { expectations }\end{array}$ & 4.37 & 4.01 & 3.80 & 1.95 & 32.74 & $\mathbf{0 . 0 0}$ \\
\hline
\end{tabular}




\section{Issues in Information Systems}

Volume 18, Issue 1, pp. 1-10, 2017

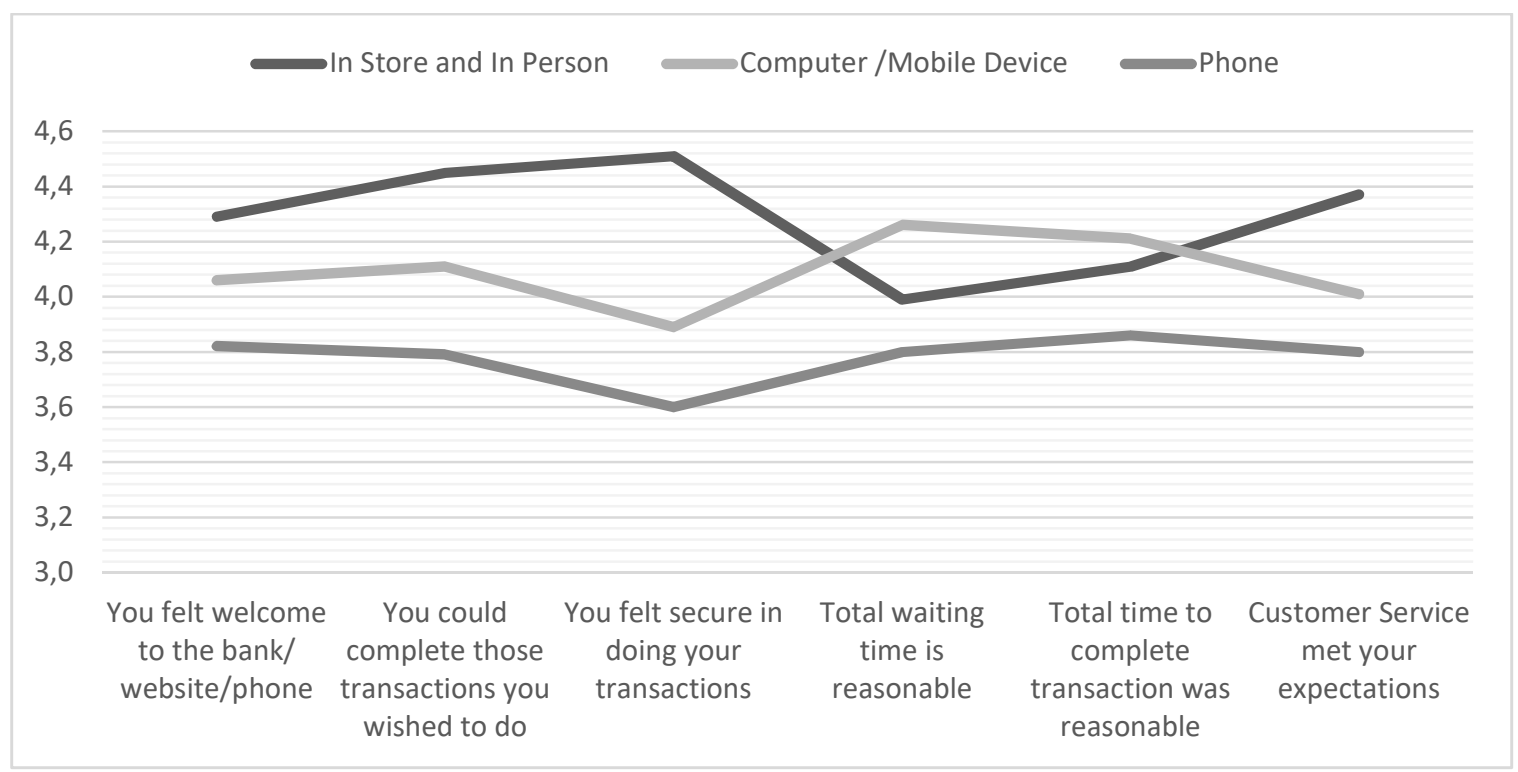

Figure 3. Banking

Table 6 shows that for banking, there exist significant difference among three modes. Figure 3 shows that for banking, in store and in person received highest means for most of service quality measures (4/6), followed by computer/mobile device and phone which received lowest mean.

Table 7. Travel

\begin{tabular}{|l|r|r|r|r|r|c|}
\hline & \multicolumn{3}{|c|}{$\begin{array}{l}\text { Mean for Each Mode of Ticket } \\
\text { Purchasing }\end{array}$} & \multicolumn{3}{c|}{ Greenhouse-Geisser } \\
\hline & $\begin{array}{l}\text { In Store } \\
\text { and In } \\
\text { Person }\end{array}$ & $\begin{array}{l}\text { lomputer } \\
\text { /Mobile } \\
\text { Device }\end{array}$ & Phone & $\begin{array}{l}\text { Degree of } \\
\text { Freedom }\end{array}$ & F & Significance \\
\hline $\begin{array}{l}\text { You felt welcome at the counter } \\
\text { or at the website/phone }\end{array}$ & 3.91 & 3.97 & 3.62 & 1.78 & 13.99 & $\mathbf{0 . 0 0}$ \\
\hline $\begin{array}{l}\text { You could complete those } \\
\text { transactions you wished to do }\end{array}$ & 4.04 & 4.17 & 3.74 & 1.96 & 24.60 & $\mathbf{0 . 0 0}$ \\
\hline $\begin{array}{l}\text { Checkout and payment was } \\
\text { quick enough }\end{array}$ & 3.75 & 4.14 & 3.69 & 1.81 & 24.91 & $\mathbf{0 . 0 0}$ \\
\hline $\begin{array}{l}\text { You felt secure in doing your } \\
\text { transactions }\end{array}$ & 4.12 & 3.96 & 3.57 & 1.93 & 35.85 & $\mathbf{0 . 0 0}$ \\
\hline Total waiting time is reasonable & 3.52 & 4.19 & 3.63 & 1.86 & 40.64 & $\mathbf{0 . 0 0}$ \\
\hline $\begin{array}{l}\text { Total time to complete } \\
\text { transaction was reasonable }\end{array}$ & 3.74 & 4.16 & 3.65 & 1.94 & 27.09 & $\mathbf{0 . 0 0}$ \\
\hline $\begin{array}{l}\text { Customer Service met your } \\
\text { expectations }\end{array}$ & 3.94 & 4.00 & 3.66 & 1.88 & 13.18 & $\mathbf{0 . 0 0}$ \\
\hline
\end{tabular}

Table 7 shows that for travel, there exist significant difference among three modes. Figure 4 shows that for traveling, purchasing through computer/mobile device received highest means for all service quality measures except one item (you felt secure in doing your transaction), followed by in store and in person, and phone received the lowest mean for all measures. Those are consistent with our earlier findings, showing students chose computer/mobile device as their most preferred way of purchasing travelling tickets. 


\section{Issues in Information Systems}

Volume 18, Issue 1, pp. 1-10, 2017

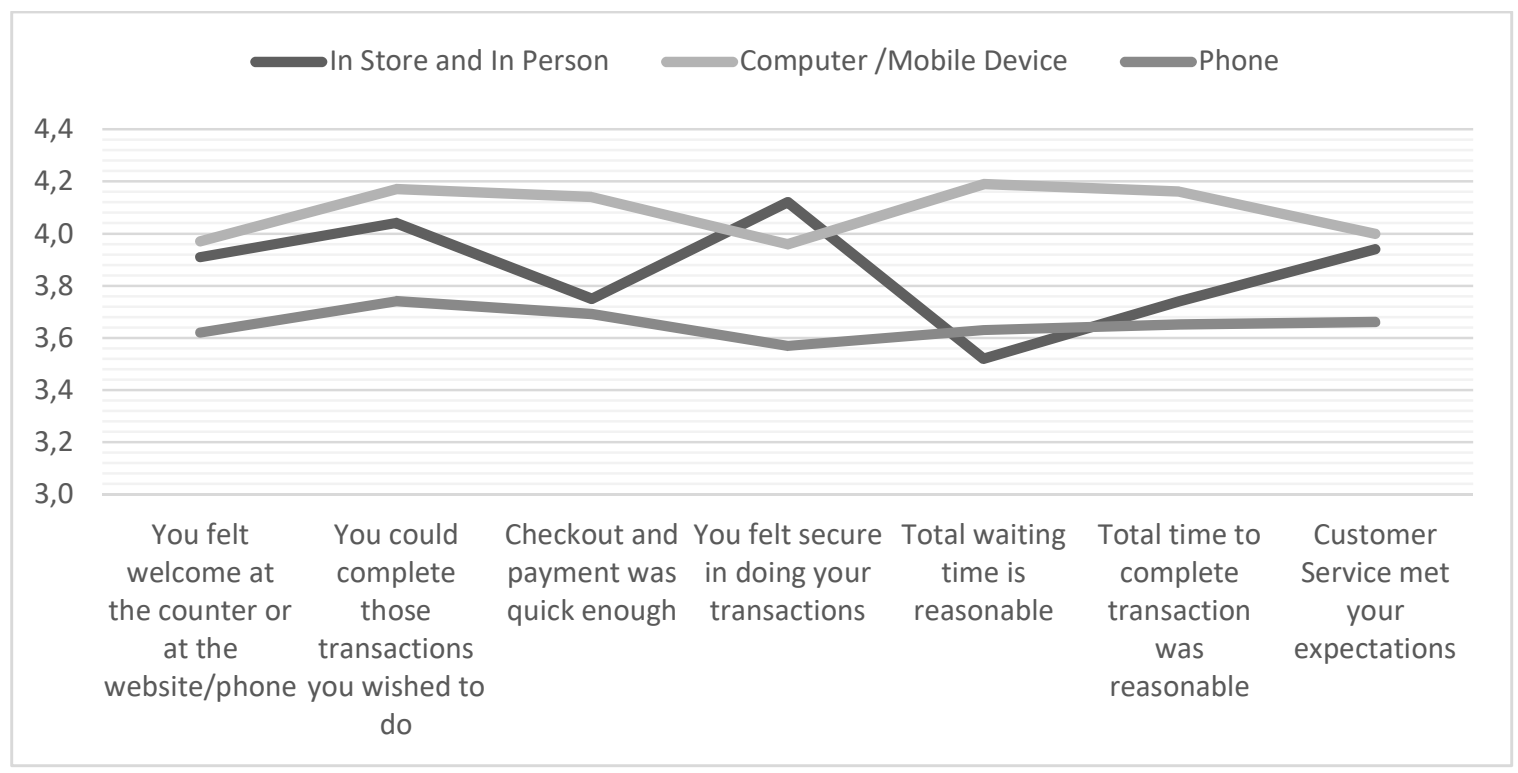

Figure 4. Travel

Table 8 shows that for entertainment, there exists significant differences among three modes. Figure 5 shows that for entertainment, purchasing through computer/mobile device received highest means for all service quality measures except one item (you felt secure in doing your transaction), followed by in store and in person and phone received lowest mean for all measures. This pattern is the same as for travel.

Table 8. Entertainment

\begin{tabular}{|l|r|r|r|r|r|c|}
\hline & \multicolumn{3}{|c|}{ Mean for Each Mode of Ticket } & \multicolumn{3}{c|}{ Greenhouse-Geisser } \\
\hline & \multicolumn{1}{|c|}{$\begin{array}{l}\text { In Store } \\
\text { and In } \\
\text { Person }\end{array}$} & $\begin{array}{l}\text { lomputer } \\
\text { /Mobile } \\
\text { Device }\end{array}$ & Phone & $\begin{array}{l}\text { Degree of } \\
\text { Freedom }\end{array}$ & F & Significance \\
\hline $\begin{array}{l}\text { You felt welcome at the counter } \\
\text { or at the website/phone }\end{array}$ & 4.15 & 4.17 & 3.76 & 1.80 & 21.50 & $\mathbf{0 . 0 0}$ \\
\hline $\begin{array}{l}\text { You could complete those } \\
\text { transactions you wished to do }\end{array}$ & 4.23 & 4.33 & 3.79 & 1.71 & 33.41 & $\mathbf{0 . 0 0}$ \\
\hline $\begin{array}{l}\text { Checkout and payment was } \\
\text { quick enough }\end{array}$ & 3.98 & 4.31 & 3.72 & 1.83 & 27.77 & $\mathbf{0 . 0 0}$ \\
\hline $\begin{array}{l}\text { You felt secure in doing your } \\
\text { transactions }\end{array}$ & 4.26 & 4.20 & 3.70 & 1.78 & 34.49 & $\mathbf{0 . 0 0}$ \\
\hline Total waiting time is reasonable & 3.87 & 4.33 & 3.79 & 1.82 & 29.61 & $\mathbf{0 . 0 0}$ \\
\hline $\begin{array}{l}\text { Total time to complete } \\
\text { transaction was reasonable }\end{array}$ & 3.95 & 4.29 & 3.77 & 1.83 & 22.67 & $\mathbf{0 . 0 0}$ \\
\hline $\begin{array}{l}\text { Customer Service met your } \\
\text { expectations }\end{array}$ & 4.09 & 4.16 & 3.79 & 1.74 & 16.84 & $\mathbf{0 . 0 0}$ \\
\hline
\end{tabular}




\section{Issues in Information Systems \\ Volume 18, Issue 1, pp. 1-10, 2017}

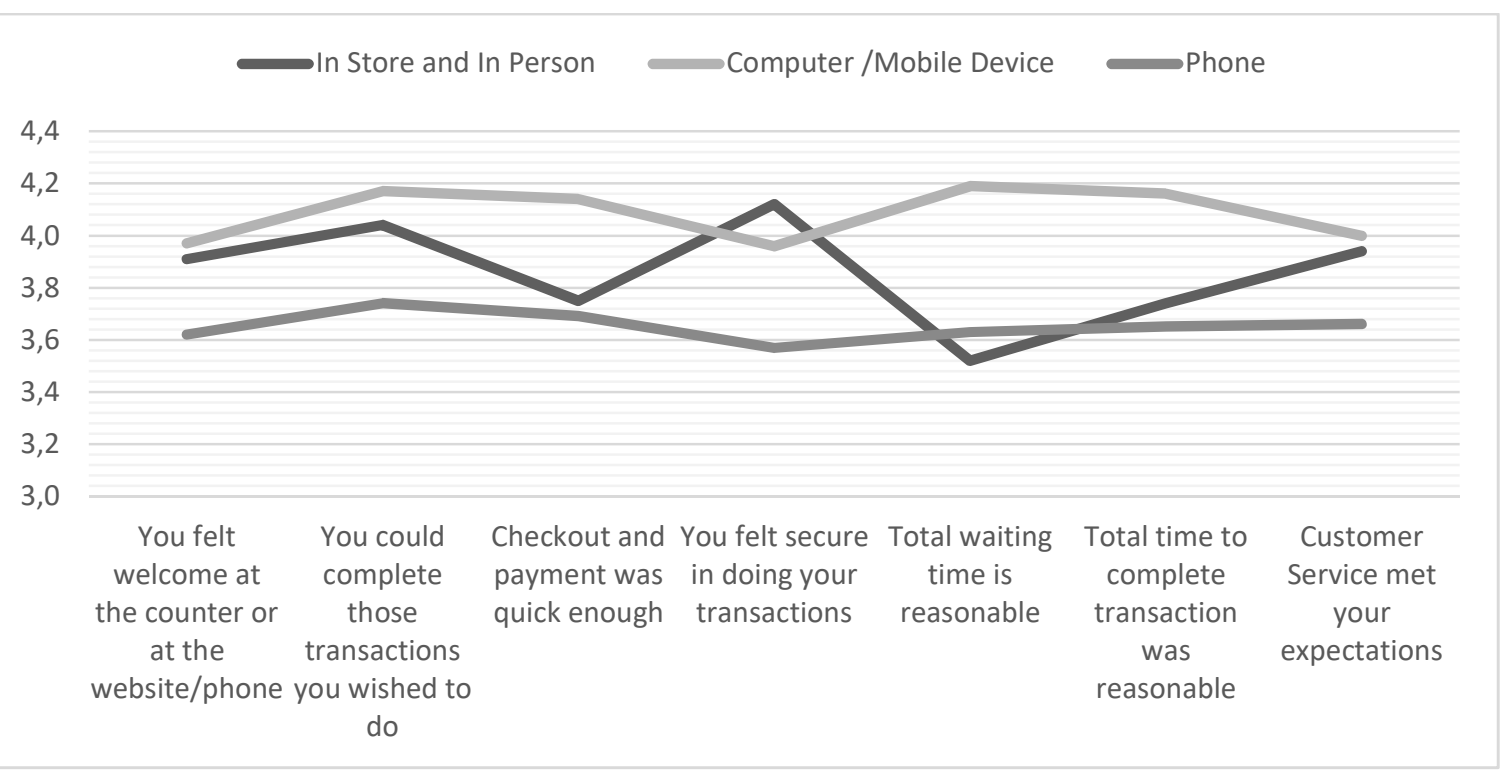

Figure 5. Entertainment

\section{CONCLUSIONS}

- Retail - A majority of respondents prefer in store and in person. Security deemed higher in store than online, time to complete transactions similar between in store and on-line.

- Eating Out - A majority of respondents prefer in store and in person. Security deemed higher in store than on-line, time to complete transactions similar between in store and on-line.

- Banking - About half respondents prefer in person services, and about one third (35\%) prefer computer and mobile devices, and the rest (14\%) prefer phone. Security deemed higher in store than on-line, time to complete transactions more favorable on line than in store.

- Travel - A majority of respondents prefer computer/mobile device. Security slightly better in store than online, time to complete transactions much more favorable on-line.

- Entertainment - A majority of respondents prefer computer/mobile device. Security slightly better in store than on-line, time to complete transactions much more favorable on-line.

In sum, our results show the majority of the respondents prefer either in-store or online in today's customer service and phone (voice-based) purchasing is slowly disappearing. In addition, customers' preference on mode of purchasing differ based on type of purchasing. It can be seen that for all type of purchasing, customers feel more secure when conducting purchasing in store than on-line, while they feel it more time-consuming to complete transactions in store than online. For companies operating both in-store and online, they should strive to improve online security and shorten in-store transaction time in order to increase the quality of their customer services.

Customer service strategy is in play, is becoming progressively more technology mediated, and may be a significant driver of the switch from mall shopping to on-line shopping because the checkout process is becoming a more time consuming part of the "bricks" shopping experience. Cash registers are slow and frequently paired with noisy printers. An increase in the ratio of self service to full service checkout in retail results in empty self-checkout and unnecessarily longer lines at full service. Check out employees are expected to sell credit card and other services to customers as they check out. Results of this paper show that the survey population is not satisfied with current IT mediated customer service, and hence there is a need for businesses to reassess and reformulate their approach to IT mediated service, particularly as it relates to customer check out that is not on-line. 


\section{Issues in Information Systems \\ Volume 18, Issue 1, pp. 1-10, 2017}

Companies should first review their strategies for customer service and adjust their rate of IT mediated customer service, in order to more closely match customer willingness to embrace these changes, and second should consider the financial advantages of a fundamental change in their business model that reduces their total number of store fronts and converts others to "touch and feel" showrooms from which items can be ordered on-line.

\section{FUTURE RESEARCH}

Areas of future research for information technology mediated customer service should include development of a model that links current customer adaptation realities to profit motivated changes in customer service, and another that measures customer willingness to integrate on-line ordering with showroom viewing. Future study can expand current study by including other types of purchasing or by conducting the same survey in another country so that country differences can be identified. It is also of interest to investigate the impact of contextual factors (such as personality, age and gender) on IT mediated customer service.

\section{REFERENCES}

Chakrabarti, C. \& Luger, G. (2015). Artificial conversations for customer service chatter bots: Architecture, algorithms, and evaluation metrics. Expert Systems with Applications, 42, 6878-6897.

Clarke, P. \& Murray, D. (1990). Information Technology in Customer Service, Business Quarterly, 54(4), 91.

Davis, F. (1989). Perceived usefulness, perceived ease of use, and user acceptance of information technology. MIS Quarterly, 13(3), 319-340.

Domegan, C. \& Donaldson, B. (1992). Customer Service and Information Technology. Journal of Information Technology, 7, 203-212.

Israeli, A. \& Brown, R. (2015). An Approach for Determining the Mix between Human and Automated Service Providers, Journal of Multi-Criteria Decision Analysis, 22, 75-88.

Lee, H.-J. \& Lyu, J., (2016). Personal values as determinants of intentions to use self-service, Computers in Human Behavior, 60, 322-332.

McWilliams, A. \& Anistal, M. (2016). Customer Versus Employee Perceptions: A Review of Self-Service Technology Options as Illustrated in Self-Checkouts in U.S. Retail Industry, Academy of Marketing Studies Journal, 20(1), 79 .

Moore, G. (1965). Cramming More Components onto Integrated Circuits, Electronics, 114-117.

Pulach, S. \& Wunderlich, N. (2016). Contrasting risk perceptions of technology-based service innovations in interorganizational settings. Journal of Business Research, 69(7), 2424-2431.

Quiring, K., DeAngelis, F. \& Gasull, E. (2016). Digital disconnection in customer engagements. Available at: www.accenture.com/us-en/insight-digital-disconnect

Scherer, A., Wünderlich, N., \& von Wangenheim, F. (2015). The Value of Self-service: Long-term Effects of Technology-based Self-Service Usage on Customer Retention. MIS Quarterly, 39(1), 177-200. 